The 23rd Lung Cancer Mass Screening Seminar

\title{
環境中に飛散した石綿はどこまで影響が及ぶか
}

\author{
車谷典男 1 熊谷信二 2
}

\section{Brief Review on the Range of the Affected Area by Neighborhood Exposure to Industrial Origin Asbestos}

\author{
Norio Kurumatani1; Shinji Kumagai2 \\ ${ }^{1}$ Department of Community Health and Epidemiology, Nara Medical University School of Medicine, Japan; ${ }^{2}$ Department of En- \\ vironmental Health, Osaka Prefectural Institute of Public Health, Japan.
}

\begin{abstract}
Because asbestos has been extensively used in the world since the early 20th century, there are many factories which have now stopped handling asbestos and asbestos-containing products. Therefore an investigation on the range of the affected area by neighborhood exposure is important to interpret a causal inference about mesothelioma encountered among residents and to create policies for protecting the community from asbestos-related health hazards. In the present paper we made a brief review on this issue. Few studies have focused on the mortality risk of mesothelioma among residents and the residential distance from an asbestos source of industrial origin. Those studies revealed that a significantly increased mortality risk of mesothelioma was observed within half a mile of an asbestos factory in London, within 1,000 and 2,000 meters of asbestos mines, asbestos factories or shipyards in South Africa and some European countries, respectively, and beyond 2,500 meters of an asbestos cement factory in Italy. Our study on mesothelioma deaths around a now-closed asbestos cement pipe plant also indicated that an increased mortality risk of the disease was found in the area as far as 1,500 meters away from the plant. Public health policymakers, health professionals and companies should recognize that neighborhood exposure to asbestos can pose a serious risk of mesothelioma to residents over a wide area.
\end{abstract}

KEY WORDS — Asbestos, Epidemiological studies, Neighborhood asbestos exposure, Mesothelioma

(JJLC. 2009;49:63-68)

Reprints: Norio Kurumatani, Department of Community Health and Epidemiology, Nara Medical University School of Medicine, 840 Shijyocho, Kashihara-shi, Nara 634-8521, Japan (e-mail: knorio@naramed-u.ac.jp).

要旨——石綿は 20 世紀初頭から世界各地で大量に使用 されてきたため，石綿または石綿製品の取扱い事業場は 現在も含め数多くある。 それ故, 石綿が近隣に及ぼす影 響範囲の検討は，一般住民に発見される中皮腫の石綿曝 露源を考える上でも，地域全体を石綿関連疾患から予防 するためにも重要である，本稿ではその影響範囲に関す る文献的解説を試みた。事業場活動を原因とする石綿曝 露源と周辺住民の中皮腫による死亡リスク上昇との関連 を検討した研究は実は極めて少ない。しかし，それらの 研究によれば，英国ロンドンの石綿製造工場の場合は $800 \mathrm{~m}$ 以内で, 南アフリカとヨーロッパ諸国の石綿鉱山
や石綿製品製造工場，さらには造船所の場合はそれぞれ $1,000 \mathrm{~m}$ と $2,000 \mathrm{~m}$ 以内で, またイタリアの石綿セメント 工場の場合には $2,500 \mathrm{~m}$ を超えても，中皮腫死亡の有意 なリスク上昇が認められている．著者らが検討した旧石 綿セメント管製造工場近隣住民の中皮腫死亡リスクも, 工場から $1,500 \mathrm{~m}$ 離れた所まで有意な上昇を認めた．公 衆衛生担当者と医療関係者そして企業は，石綿の近隣曝 露が広い範囲にわたって中皮腫の重大なリスク上昇をも たらすことを十分認識する必要がある.

索引用語——石綿, 疫学研究, 近隣石綿曝露, 中皮腫
1奈良県立医科大学地域健康医学教室 ; 2 大阪府立公衆衛生研究 所生活環境部.

別刷請求先：車谷典男, 奈良県立医科大学地域健康医学教室,
T634-8521 奈良県橿原市四条町 840 (e-mail: knorio@naramed-u. ac.jp) . 


\section{I. 石綿と中皮腫}

中皮腫と石綿との関連性を初めて明確に指摘したの は，ヨハネスバーグのじん肺研究機関の病理医であった Wagner ら1である．相次いで経験した中皮腫症例の中 に,クロシドライト鉱山周辺や石綿堆積場で子供の頃に 遊んでいた者と，病理組織学的に石綿肺所見が証明され る者とを彼らは見いだした。このことを契機に，胸膜中 皮腫 33 例について職業歴と居住歴などに関する case series analysis を行ない, 18 人に職業性曝露歴があり, 残 る者のうち 1 人には家庭内曝露が, そして 13 人には職業 性の曝露歴はないもののクロシドライト鉱山近隣での居 住歴があったことを明らかにした。

石綿取扱い事業場から環境中に飛散した石綿が，どの 範囲の地域に影響を及ぼすかの知見は, 診療現場で遭遇 する中皮腫症例の石綿嚗露源を判断する臨床医にとって も，地域住民の健康対策を立案実行すべき地域保健行政 にとっても重要である。しかし，近隣曝露に関する疫学 研究は上述の Wagner 以来, 10 数件 2,3 を数えるが, 具体 的な影響範囲についての研究は，石綿鉱山を含めて石綿 取扱い事業場が国内外に多く存在したにもかかわらず， 現在に至るも極めて少ない，本論では，著者らが経験し た兵庫県尼崎市の旧石綿セメント管製造工場近隣の中皮 腫発生事例 4 含めて，工場住居間の距離に言及した研 究を取り上げ, 石綿の近隣曝露がどの程度の範囲まで影 響が及び得るかを紹介する。

\section{II. 近隣曝露に関する海外の疫学的知見}

\section{1. 英国の石綿製品製造工場の近隣曝露事例（1965 年）}

Newhouse ら 5 は, 1917 年から 1964 年までに英国のロ ンドン内の病院で病理組織検査により中皮腫と診断され た 83 人を症例とした症例対照研究を行っている. 職歴と 居住歴が判明した症例 76 人のうち 31 人には職業性の石 綿曝露歴があった。この 31 人と家庭内曝露のあった 9 人を除いた残り 36 人中 11 人 $(30.6 \%)$ に石綿製品製造工 場（Cape Asbestos 工場）から 0.5 マイル $(800 \mathrm{~m})$ 以内 の居住歴があり，対照群 67 人中の 5 人 $(7.5 \%)$ に比べ有 意に多かったことが示されている。オッズ比を計算する と $5.2(95 \%$ 信頼区間：1.7〜 17.5) となる. 同工場では, クロシドライトを中心に少量のアモサイトとクリソタイ ルが使用されていたが，使用量についての記述はない． 初回曝露から死亡時までの平均潜伏期間は, 職業性曝露 群の 29.4 年や家庭内曝露群の 37.9 年に比へ, 近隣曝露群 は 48.6 年と長いことも報告されている．上記の Wagner らの研究では, 近隣との表現のみで距離は示されていな いため, この Newhouse らの報告が工場周辺地域の影響 範囲を具体的に示した最初の研究である。

\section{2. 米国の石綿製品製造工場の近隣曝露事例（1997 年）}

米国 New Jersey 州 Somerset 郡に位置して 約 $3 \mathrm{~km}$ 四方の面積を持つ Manville 地区の北東角に, 北米最大の 石綿製品製造工場があった。1912 年から 1980 年までの 操業期間中, 最も多い時期には 3,500 人の労働者が雇用 されていたという. 石綿の使用量などは不詳であるが, 95\%までがクリソタイルであったとされている. Berry 6 は, New Jersey 州の癌登録を用いて，工場周辺の 1979 年から 1990 年までの中皮腫の罹患リスクを検討し, 州全 体の年齢調整罹患率 (年間 100 万人あたり) は男性 24.7 , 女性 4.1 であったのに対し, Manville 地区 (人口約 11,000 人)では男性 635.6, 女性 95.9 との高い值を得ている.さ らに，上記工場の労働組合員名簿などから職業性曝露の 可能性がある者を除外した中皮腫の SIR（standardized incidence ratio：標準化罹患比）を算出し，男性 10.1 (5.8〜 16.4), 女性 $22.4(9.7 \sim 44.2)$ と，いずれも有意な過 剩発生が認められたことを報告している。ただし，家庭 内曝露の有無が検討できていないため, 過大評価の可能 性はある。

\section{3. 英国の石綿製品工場などの近隣曝露事例（1997 年）}

英国では 1980 年代に中皮腫罹患率の高い地域の存在 が社会的な関心を集めた。 その中でイングランド北部の 都市 Leedsでの近隣曝露が問題となり，Leeds を含む Yorkshire 地区 (Leeds, Calderdale, York, Wakefield) で症例対照研究7 が行われた。1958 年に閉鎖された Leeds の工場は主にクロシドライトを使用して，紡織 品・断熱材・フィルターなど様々な石綿製品を製造し, 1970 年に閉鎖された Calderdale の工場はクロシドライ トとアモサイトとクリソタイルを使用していた．Yorkshire 地区の 1979 年から 1991 年までの死亡者で, 病理組 織検査により中皮腫と確定診断された症例と，性・死亡 年齢・死亡時期を一致させた対照に，遺族の面接調查な どを行い，職歴・居住歴・同居者の職歴などの情報を得 ている. 症例 185 人と対照 159 人が解析対象となったが, 職業性曝露「あり」と「可能性あり」の者を除外し，さ らに家庭内曝露「あり」と「可能性あり」の者も除外す ると, 症例 14 人と対照 56 人が残った。これらの中でい ずれかの石綿製品工場から $500 \mathrm{~m}$ 以内に居住歴がある 者はいずれも 5 人で，そのオッズ比は $6.6(0.86 \sim 50)$ ，こ れに石綿製品倉庫から $500 \mathrm{~m}$ 以内の居住歴のあった者 を加えると症例 6 人に対して対照 9 人で，そのオッズ比 は $2.3(0.54 \sim 9.7)$ であったと報告されている。

\section{4. 南アフリカの石綿鉱山などの近隣曝露事例（1999} 年)

南アフリカにはいくつかの石綿鉱山があった．Cape 州北西部にクロシドライト鉱山, Transvaal 州北東部に クロシドライト鉱山とアモサイト鉱山，そして同州東部 
Table 1. Adjusted Odds Ratio (OR) for Mesothelioma According to Nature of Asbestos Exposure ${ }^{8}$

\begin{tabular}{lcc}
\hline Asbestos exposure & OR & $95 \% \mathrm{CI}$ \\
\hline Nature & & \\
$\quad$ Occupational & 80.6 & $15.7-414$ \\
$\quad$ Environmental & 19.6 & $3.7-105$ \\
$\quad$ “Risk” occupation & 15.9 & $2.9-84.3$ \\
Occupational & & \\
$\quad$ Mining Cape crocidolite & 85.5 & $14.5-505$ \\
$\quad$ Insulation & 76.4 & $14.4-406$ \\
$\quad$ Asbestos cement & 27.7 & $4.9-154$ \\
Environmental & & \\
$\quad$ NW Cape & 32.7 & $8.1-131$ \\
$\quad$ NE Transvaal & 12.7 & $1.9-84.7$ \\
\hline
\end{tabular}

A referent group consisted of those who were unlikely to have been exposed to asbestos in any form. OR was mutually adjusted by multiple logistic regression analysis.

にクリソタイル鉱山があった. 1893 年に採鉱が始まり， 生産量は 1977 年の 38 万トンをピークに, 1985 年には 16 万トンに減少し, 2002 年に全ての鉱山が閉鎖になってい る.こうした鉱山があった 6 つの都市（Greater Bloemfontein, Cape Town, Johannesburg, Kimberley, Port Elizabeth, Pretoria)の病院で, 1988 年から 1990 年代前 半にかけて中皮腫と確定診断された患者について症例対 照研究8 が行われている. 症例は病理組織検査で中皮腫 と診断された 123 人である. 面接調査で症例と対照の職 歴・居住歴・両親の職業性石綿曝露歴などに関する情報 を得ている. 石綿鉱山付近の污染地区(距離は決めず)で の居住歴，あるいは石綿工場や石綿倉庫または造船所か ら $1 \mathrm{~km}$ 以内での居住歴がある場合に「近隣曝露あり」と されている. 症例 123 人と対照 222 人を対象としたロジ スティク回帰分析による調整済みオッズ比 (Table 1) は, 近隣曝露の場合, Cape 州北西部 (NW Cape)のクロシド ライト鉱山近隣が 32.7 と最も高く, Transvaal 州北東部 （NE Transvaal）のクロシドライト鉱山およびアモサイ ト鉱山の近隣は 12.7 で, これらに対して同州東部のクリ ソタイル鉱山では近隣曝露例は認められていない.

\section{5. 欧州 3 か国の石綿工場などの近隣曝露事例 (2000 年)}

イタリア，スペインおよびスイスの 6 地域（Torino, Casale, Firenze, Barcelona, Cadiz, Geneve)で多施設 共同研究が行われている. Torinoには石綿紡織工場・絶 縁材工場・車両工場が, Casale および Barcelona には石 綿セメント工場が, Firenze および Cadizには造船所が あったが, これらの地域で 1993 年から 1997 年の間に病 理組織検査で胸膜中皮腫と診断された患者の症例対照研
Table 2. Risk of Pleural Mesothelioma According to Levels of Environmental Exposure to Asbestos ${ }^{9)}$

\begin{tabular}{lrrrc}
\hline & $\begin{array}{c}\text { Case } \\
\mathrm{n}(\%)\end{array}$ & $\begin{array}{c}\text { Control } \\
\mathrm{n}(\%)\end{array}$ & OR & $95 \% \mathrm{CI}$ \\
\hline No or background exposure & $20(37.7)$ & $176(75.9)$ & 1 & - \\
Low intensity & $6(11.3)$ & $19(8.2)$ & 2.23 & $0.65-7.64$ \\
Middle intensity & $13(24.5)$ & $19(8.2)$ & 9.48 & $2.46-36.5$ \\
High intensity & $6(11.3)$ & $3(1.3)$ & 45.0 & $6.38-318$ \\
Unknown & $8(15.1)$ & $15(6.5)$ & 3.42 & $1.15-10.2$ \\
\hline
\end{tabular}

究9 が行われている. 本人あるいは遺族の面接調査を行 い, 契煙 - 放射線治療歴 - 職歴 - 同居者の職歴 - 居住 歴・周辺環境についての情報を得ている. 解析対象は症 例 215 人と対照 448 人であったが, 職業性曝露が確実な 者と可能性がある者を除いて残った症例 53 人と対照 232 人について近隣曝露のリスクを評価している (Table 2). その結果, 石綿鉱山・石綿セメント工場・石綿織物 工場・造船所あるいはブレーキライニング工場から 500 $\mathrm{m}$ 以内の居住歴がある者（high intensity）の調整済み オッズ比は 45.0, $500 \mathrm{~m}$ から $2,000 \mathrm{~m}$ までの居住歴があ る者 (middle intensity) は 9.48, 2,000 m か 5,000 m までの居住歴あるいは製鋼所・発電所・大規模化学工場 などから $500 \mathrm{~m}$ 以内での居住歴がある者 (low intensity) は 2.23 であったことが報告されている. 曝露源から $2,000 \mathrm{~m}$ までが有意なリスク上昇ということになる.

\section{6. イタリアの石綿セメント工場の近隣曝露事例（2001} 年)

イタリア北西部に位置する人口 41,700 人の町 Casale Monferratoにあった同国最大の Eternit 石綿セメント 工場は, 同町の中心部から風上方向に $1,500 \mathrm{~m}$ の所で, 1907 年から 1986 年まで稼動していた. 石綿ボード・石 綿スレート・石綿セメント管などの製造にクロシドライ トとクリソタイルが使用されていた.アモサイトは使用 されていない. 生産量が急減した 1981 年の石綿使用量は 総量 15,000 トン, そのうち $10 \%$ がクロシドライトで あった. Magnani ら10は，この町を含む地域で 1987 年か ら 1993 年までに胸膜中皮腫と診断された患者の症例対 照研究を実施している。職歴や居住歴などの情報を面接 調査で得て, Eternit 石綿セメント工場での勤務歴がない 者を同石綿セメント工場から居住地までの距離で分類 し, Casale から遠方の地域住民の中皮腫死亡状況を基準 に，家庭内曝露の有無を調整したオッズ比を算出してい る (Table 3). 中皮腫死亡者のうち居住歴が同工場の 500 $\mathrm{m}$ 以内にあった者の調整オッズ比は $27.7,500 \sim 1,499 \mathrm{~m}$ が 22.0, 1,500〜 2,499 $\mathrm{m}$ が 21.0, 2,500 $\mathrm{m}$ 超で 11.1 と, い ずれも有意に 1 を上回っていることが示されている．居 住年数は触れられていない.こうした近隣曝露の曝露源 
Table 3. Risk of Mesothelioma in Relation to Residence in Different Municipalities in Casale Monferrato, North Italy ${ }^{10)}$

\begin{tabular}{lcccc}
\hline \multicolumn{1}{c}{ Subjects } & $\begin{array}{c}\text { Case } \\
\mathrm{n}(\%)\end{array}$ & $\begin{array}{c}\text { Control } \\
\mathrm{n}(\%)\end{array}$ & OR & 95\%CI \\
\hline $\begin{array}{l}\text { Occupation in the AC industry } \\
\begin{array}{l}\text { Ever lived in Casale, distance from the } \\
\text { AC industry }\end{array}\end{array}$ & $27(26.5)$ & $13(5.4)$ & 52.5 & $12.5-220.0$ \\
$\quad<500 \mathrm{~m}$ & $5(4.9)$ & $2(0.8)$ & 27.7 & $3.1-247.7$ \\
$\quad 500-1,499 \mathrm{~m}$ & $41(40.2)$ & $52(21.4)$ & 22.0 & $6.3-76.5$ \\
$\quad 9(8.8)$ & $12(4.9)$ & 21.0 & $4.9-91.8$ \\
$\quad>00-2,499 \mathrm{~m}$ & $4(3.9)$ & $9(3.7)$ & 11.1 & $1.8-67.2$ \\
$\quad \begin{array}{l}\text { Ever lived in any of the municipalities } \\
\text { surrounding Casale }\end{array}$ & $12(11.8)$ & $42(17.3)$ & 8.3 & $2.1-32.6$ \\
$\begin{array}{l}\text { Never in any of the above-mentioned } \\
\text { categories }\end{array}$ & $4(3.9)$ & $113(46.5)$ & 1.0 (Ref) \\
\hline
\end{tabular}

AC: asbestos cement pipe plant in Casale Monferrato. OR: adjusted odds ratio by multiple logistic regression analysis.

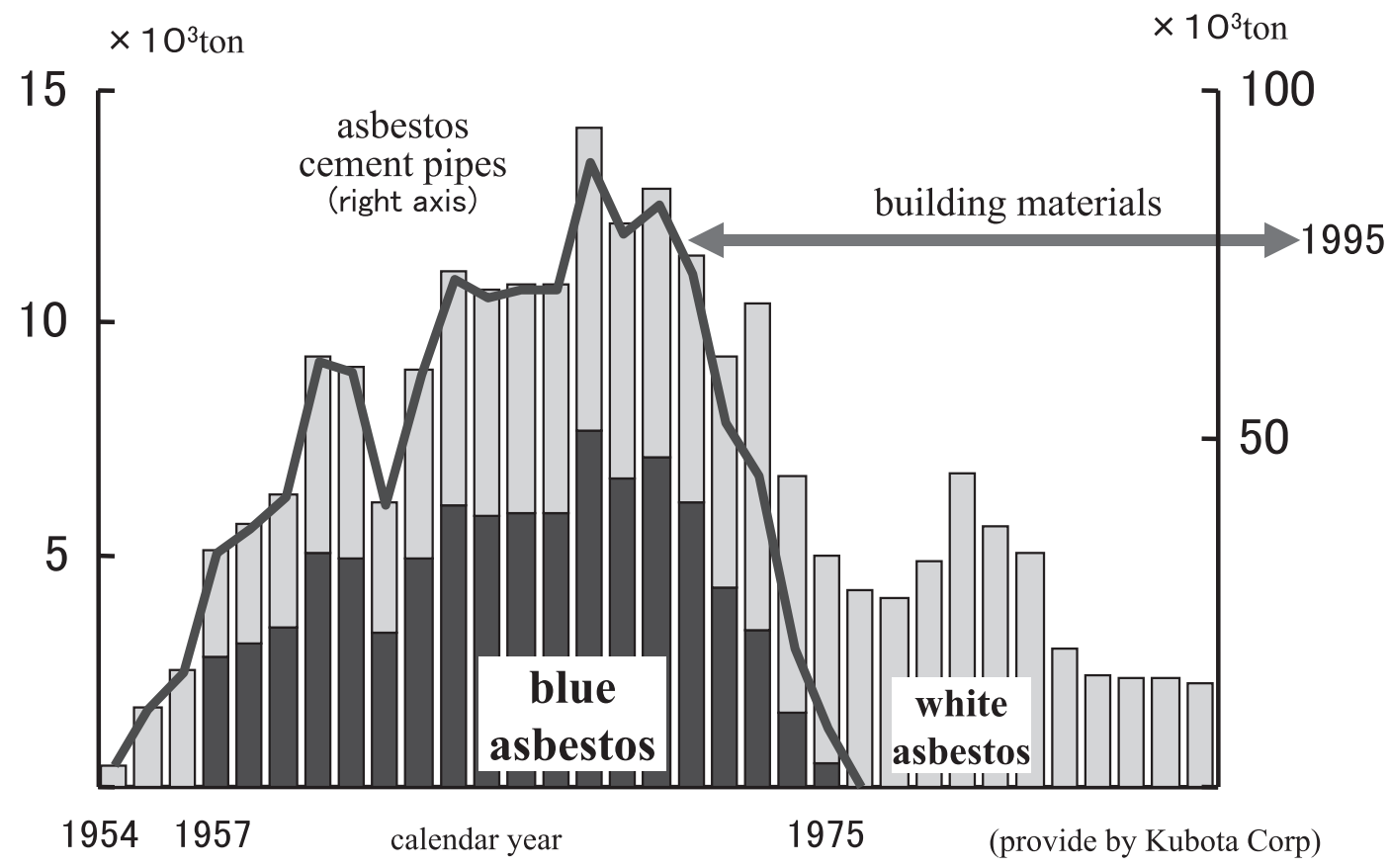

Figure 1. Asbestos consumption in the asbestos cement pipe plant.

として，同石綿セメント工場に加えて，例えば，歩道を 固めたり運動場の水はけをよくしたりするために使用さ れた同工場からの石綿や石綿セメント製品のくず，石綿 原料の輸送経路なども想定されている.

\section{III. 尼崎市の旧石綿管製造工場の近隣曝露事例}

2005 年 6 月 29 日の新聞報道が発端となったわが国の 事例である. 国内有数の石綿セメント管製造工場であっ たクボタ旧神崎工場 (兵庫県尼崎市) は, 操業開始当初, 空き地が多い所に立地していたが，経済成長とともに周
辺に人家が立ち並び, 結果として人口密度の高い地区の 中心に位置することになった. 石綿セメント管は, セメ ントを中心にクリソタイルとクロシドライトを加えたも ので, 上水道の配水管や導水管, 工業用水道配管などを 用途としていた. 1957 年から石綿管製造が中止される 1975 年までの間に, 多い年では約 7,700 トン, 年平均約 4,700 トンのクロシドライトが使用されていた（Figure 1). 同工場では 1978 年から 2004 年までの間に従業員 84 人が石綿関連疾患を発症している.中皮腫は 1986 年の第 1 例に始まり, 2005 年の新聞報道時点で死亡 42 人, 療養 


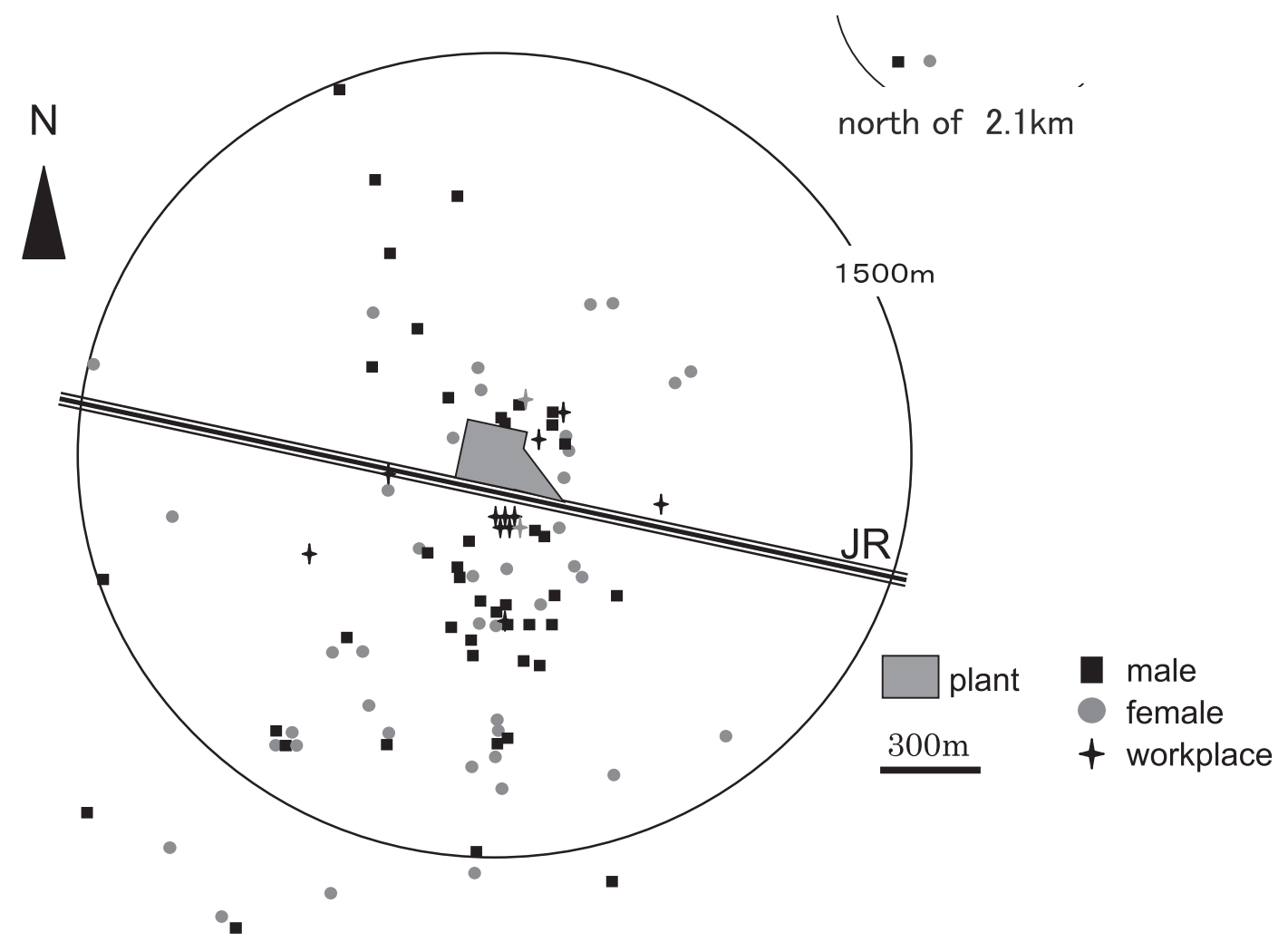

Figure 2. Location of homes or workplaces of 99 mesothelioma cases, who had no possibilities of occupational exposure to asbestos, as of Dec 31, 2005. The center of the circle with a 1,500-meter radius is the asbestos cement pipe plant.

Table 4. SMRs of Mesothelioma Deaths by Gender and Distance Among Residents Around the Asbestos Pipe Plant

\begin{tabular}{|c|c|c|c|c|}
\hline \multirow[b]{2}{*}{ Men } & \multirow{2}{*}{$\begin{array}{r}\text { Residential } \\
\text { distance }\end{array}$} & \multirow{2}{*}{$\begin{array}{c}\mathrm{O} / \mathrm{E} \\
7 / 0.45\end{array}$} & \multicolumn{2}{|c|}{ SMR (95\%CI) } \\
\hline & & & 15.5 & 7.3-31.8 \\
\hline & $300-600$ & $9 / 1.92$ & 4.7 & $2.3-9.0$ \\
\hline & $600-900$ & 8/3.03 & 2.6 & $1.2-5.2$ \\
\hline & $900-1500$ & $6 / 6.48$ & 0.9 & $0.4-2.1$ \\
\hline \multirow[t]{4}{*}{ Women } & $0-300$ & $5 / 0.14$ & 35.2 & $13.9-83.0$ \\
\hline & $300-600$ & $6 / 0.61$ & 9.9 & 4.3-21.9 \\
\hline & $600-900$ & $5 / 0.96$ & 5.2 & $2.1-12.3$ \\
\hline & $900-1500$ & $11 / 2.05$ & 5.4 & $2.8-9.7$ \\
\hline
\end{tabular}

O: observed deaths as of Dec 31, 2005. E: expected deaths based on the corresponding national mortality of mesothelioma. SMR: standardized mortality ratio.

中 4 人を数え, その病型内訳は胸膜中皮腫が 18 人, 腹膜 中皮腫が 28 人であった.

報道直後から，中皮腫と診断されたが職業性曝露は思 いあたらないとする本人・遺族などからの問い合わせが 関係者に相次ぎ，著者らはこれらの人たちについて面接
調査の機会を得た. その人数は 2006 年 3 月末で 135 人に 達した。同工場でクロシドライトが使用されていた時期 の居住地を示す住民票, 社会保険庁から交付された被保 険者記録照会回答票などをもとに, 居住地, アルバイト も含めた職歴などを聞き取った。その結果, 99 人（男性 54 人 · 女性 45 人, 死亡 85 人・治療中 14 人)については 職業性や家庭内の石綿曝露は認め難く, 病型別には 1 人 を除き全員が胸膜中皮腫であった。

Figure 2 は, クロシドライトの使用時期に，これら 99 人が 1 年以上居住または勤務していた場所と, 旧石綿管 製造工場の敷地中央を中心とした半径 $1,500 \mathrm{~m}$ の円を描 いたものである。地域分布に男女差はない。全体的には 東西方向に少なく，南北方向に多い。北側より南側に多 く，それも少し西側に偏りを見せている。こうした分布 は, この地域の風向によく一致していることを確認して いる. 中皮腫に独立した死因コード（C45）が与えられた ICD10（国際死因分類第 10 版）の施行日（1995 年 1 月 1 日）以降の, 半径 $1,500 \mathrm{~m}$ 圈内に居住歴を持つ死亡者 57 人の中皮腫死亡リスクを求めると, 男性は観察死亡数 30 人に対し日本全国の中皮腫死亡率を基礎にした推定曝露 集団の期待值は 11.9 人で SMR（standardized mortality 
ratio：標準化死亡比) は $2.5(1.8 \sim 3.6)$, 女性は 27 人に対 して期待值は 3.8 人で SMR は $7.2(4.9 \sim 10.4)$ と, 男女と もに有意なリスク上昇を示した。 さらに同心円状に地域 を分割して SMR を求めた場合 (Table 4), 半径 $300 \mathrm{~m}$ 以内では男性は 15.5 , 女性は 35.2 と極めて高い值を示し た. 男性では半径 $900 \mathrm{~m}$, 女性では半径 $1500 \mathrm{~m}$ まで中皮 腫死亡の有意なリスク上昇が認められた.

今回の著者らの調査対象者は, 新聞報道を契機に関係 者に問い合わせをしてきた人たちであることから，観察 死亡数を少なく見積もっている可能性が高い. また, 観 察值から職業性曝露があった者は除いているが, SMR の期待值の算出に用いた全国の中皮腫死亡率には職業性 曝露のある者が少なからず含まれている。これらの理由 から, 全体的にリスクの過小評価につながっている. と りわけ男性の場合, 全国死亡には職業性曝露による中皮 腫が相当程度含まれていることは容易に推測されるた め, 女性の SMR が近隣曝露のリスクをより正確に表現 していると考える.

旧石綿セメント管製造工場の近隣に居住歴があり，か つ職業性曝露のない複数の者に胸膜プラークが発見され ている報告や, クボタが公表している当時の石綿セメン 卜管製造工程は, 同工場から周辺環境中へ石綿が飛散し ていた可能性を示している。一方, 尼崎市の調査では, 同工場周辺でこれほど多量のクロシドライトを使用して いた事業所は他には発見されていない.

\section{IV. 結 論}

以上, 発生源からの影響距離が検討可能な疫学研究結 果を紹介した。使用された石綿の種類, 使用量, 作業工 程，立地条件などによって，影響が及ぶ範囲は当然異な る.ここで紹介した研究は，いずれも被害が大きいもの であり，影響範囲の上限を示していると考えるのがよい
のかも知れない. 総括的には曝露源から少なくとも 2,000 $\mathrm{m}$ 前後の範囲まで, 近隣曝露による中皮腫死亡の有意な リスクが生じ得ると判断できよう.

\section{REFERENCES}

1. Wagner JC, Sleggs CA, Marchand P. Diffuse pleural mesothelioma and asbestos exposure in the North Western Cape Province. Br J Ind Med. 1960;17:260-271.

2. Gardner MJ, Saracci R. Effects on health of nonoccupational exposure to airborne mineral fibres. IARC Sci Publ. 1989;90:375-397.

3. Bourdés V, Boffetta P, Pisani P. Environmental exposure to asbestos and risk of pleural mesothelioma: review and meta-analysis. Eur J Epidemiol. 2000;16:411-417.

4. Kurumatani N, Kumagai S. Mapping the risk of mesothelioma due to neighborhood asbestos exposure. Am J Respir Crit Care Med. 2008;178:624-629.

5. Newhouse ML, Thompson H. Mesothelioma of pleura and peritoneum following exposure to asbestos in the London area. Br J Ind Med. 1965;22:261-269.

6. Berry M. Mesothelioma incidence and community asbestos exposure. Environ Res. 1997;75:34-40.

7. Howel D, Arblaster L, Swinburne L, Schweiger M, Renvoize E, Hatton P. Routes of asbestos exposure and the development of mesothelioma in an English region. Occup Environ Med. 1997;54:403-409.

8. Rees D, Myers JE, Goodman K, Fourie E, Blignaut C, Chapman R, et al. Case-control study of mesothelioma in South Africa. Am J Ind Med. 1999;35:213-222.

9. Magnani C, Agudo A, González CA, Andrion A, Calleja A, Chellini E, et al. Multicentric study on malignant pleural mesothelioma and non-occupational exposure to asbestos. Br J Cancer. 2000;83:104-111.

10. Magnani C, Dalmasso P, Biggeri A, Ivaldi C, Mirabelli D, Terracini B. Increased risk of malignant mesothelioma of the pleura after residential or domestic exposure to asbestos: a case-control study in Casale Monferrato, Italy. Environ Health Perspect. 2001;109:915-919. 